\title{
Biology and Control of Sorghum-almum in Sugarcane ${ }^{1}$
}

\author{
Dennis Calvin Odero, Ron Rice, and Les Baucum²
}

Sorghum-almum (Sorghum almum) is an introduced grass species from Argentina. In the sugarcane production region of South Florida, it is also referred to as Columbus grass or "wild oats." Sorghum-almum is a cross between Sorghum bicolor and Sorghum propinquum (Paterson et al. 1995). Occurrence of sorghum-almum has also been reported in Alabama, Illinois, Louisiana, Mississippi, Oregon, Texas, and Wisconsin (USDA-NRCS 2012). Sorghum-almum is commonly found in the southern part of Florida in sugarcane fields and along ditches, canals, and roadsides.

\section{Biology and Life Cycle}

Sorghum-almum is a weak, perennial rhizomatous grass (SWSS 1993). Leaves of seedlings are rolled in a bud with a fringed membranous ligule. Seedlings often resemble corn seedlings when small. Stems of mature plants are stout and erect, reaching up to 14 feet tall (Figure 1). Leaf blades are flat and sandpapery. Blades are 1/2-1 1/2 inches wide by 18-32 inches long, and they are usually hairless, with long hairs occasionally at the base of the upper leaf surface.

The ligule is a prominent membrane on the basal twothirds and fringed on the top one-third (Figure 2). Leaf sheaths are open and smooth. Inflorescences are found toward the tip of the branches. Seedheads are 6-24 inches long, with wide, spreading branches (Figure 3 ). Seeds are 3/8-1/4-inch long and smooth. Propagation is by seed or

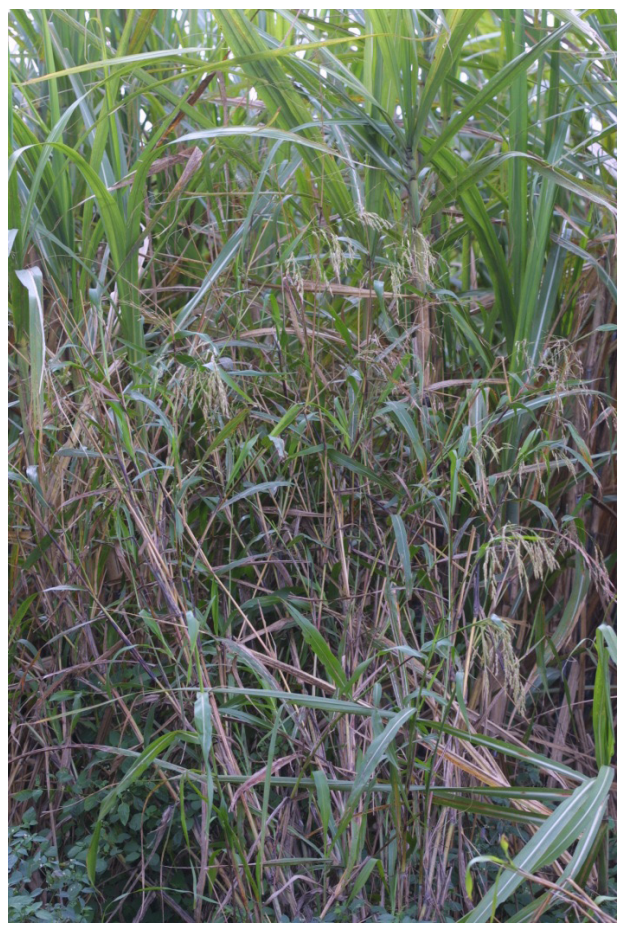

Figure 1. Sorghum-almum in sugarcane. Credits: D. C. Odero

thick underground rhizomes (runners). Because it spreads by these thick underground runners, this weed species is difficult to control in sugarcane. Optimal germination of sorghum-almum occurs at $68^{\circ} \mathrm{F}-86^{\circ} \mathrm{F}$ (Eberlein 1987). However, light is usually not very critical for its

1. This document is SS-AGR-369, one of a series of the Agronomy Department, Florida Cooperative Extension Service, Institute of Food and Agricultural Sciences, University of Florida. This publication is a part of the Florida Sugarcane Handbook. For more information, contact the editor of the Sugarcane Handbook, Ronald W. Rice (rwr@ufl.edu). Original publication date January 2013. Please visit the EDIS website at http://edis.ifas.ufl.edu.

2. Dennis Calvin Odero, assistant professor, Agronomy Department, Everglades Research and Education Center, Belle Glade, FL; Ron Rice, Extension agent, Palm Beach County, Belle Glade, FL; and Les Baucum, Extension agent, Hendry County, LaBelle, FL; Florida Cooperative Extension Service, Institute of Food and Agricultural Sciences, University of Florida, Gainesville, FL 32611.

The use of trade names in this publication is solely for the purpose of providing specific information. UF/IFAS does not guarantee or warranty the products named, and references to them in this publication do not signify our approval to the exclusion of other products of suitable composition. All herbicides should be used in accordance with directions on the manufacturer's label.

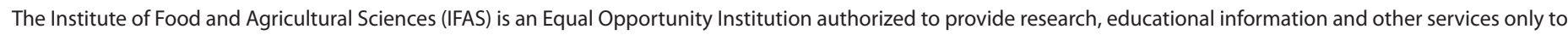

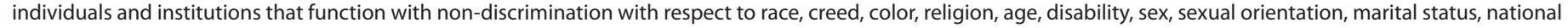
origin, political opinions or affiliations. U.S. Department of Agriculture, Cooperative Extension Service, University of Florida, IFAS, Florida A\&M University Cooperative Extension Program, and Boards of County Commissioners Cooperating. Nick T. Place, Dean 


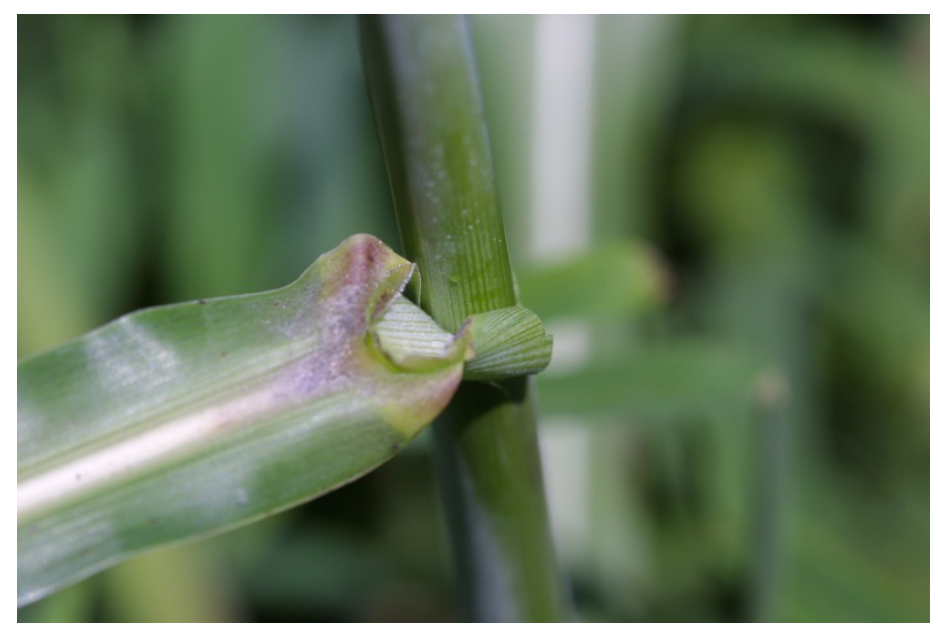

Figure 2. Sorghum-almum membranous ligule. Credits: D. C. Odero

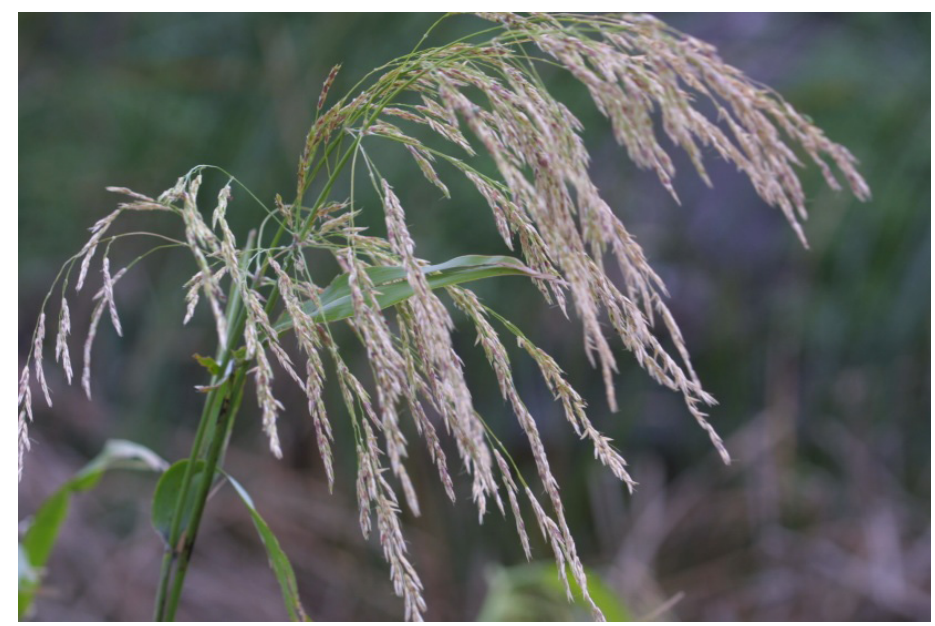

Figure 3. Sorghum-almum seedhead.

Credits: D. C. Odero

germination. Germination is usually greatest at seeding depths of 6 inches or less and declines at depths greater than 8 inches (Eberlein 1987).

\section{Control}

Sorghum-almum populations can be reduced with repeat tillage between the row middles using disk cultivators and by including fallow periods or rotational crops into a sugarcane cropping system. Currently, no herbicides are specifically labeled for selective control of sorghum-almum in sugarcane. However, some herbicides labeled for other grass species may provide some suppression in sugarcane (Table 1). Using tillage alone may create difficulty controlling perennial populations of sorghum-almum that have established thick underground runners; consequently, spot spraying with non-selective herbicides such as glyphosate can successfully reduce populations. Glyphosate at $2 \%$ solution will provide acceptable control. If the glyphosate formulation does not contain adjuvants, adding ammonium sulfate to the spray solution will improve glyphosate control.

\section{References}

Eberlein, C.V. 1987. "Germination of Sorghum almum Seeds and Longevity in Soil." Weed Science 35:796-801.

Paterson, A.H., K.F. Schertz, Y. Lin, S. Liu, and Y. Chang. 1995. "The Weediness of Wild Plants: Molecular Analysis of Genes Influencing Dispersal and Persistence of Johnsongrass, Sorghum halepense (L.) Pers." Proceedings of the National Academy of Sciences 92: 6127-31.

Southern Weed Science Society (SWSS). 1993 Weed Identification Guide. Champaign: Southern Weed Science Society.

United States Department of Agriculture, Natural Resources Conservation Service (USDA-NRCS). 2012. "Sorghum almum Parodi Columbus grass.” Accessed November 27, 2012. http://plants.usda.gov/java/profile? symbol=SOAL.

Uva, R.H., J.C. Neil, and J.M. DiTomaso. 1997. Weeds of the Northeast. Ithaca: Cornell University Press. 
Table 1. Herbicide options for suppression of sorghum-almum in sugarcane.

\begin{tabular}{|c|c|c|c|c|}
\hline Herbicide & Trade name & Rate per acre & Timing & Comments \\
\hline Metribuzin & Metribuzin & 1 1/3-2 2/3 lb & Preemergence & $\begin{array}{l}\text { Can provide suppression of seedling sorghum- } \\
\text { almum. Does not control regrowth of underground } \\
\text { runners. Apply prior to weed emergence after } \\
\text { planting or after harvest of the stubble (ratoon) crop. } \\
\text { Use on muck soils only and not on sandy (mineral) } \\
\text { soils. }\end{array}$ \\
\hline Pendimethalin & Prowl $\mathrm{H}_{2} \mathrm{O}$ & $4.2-8.4 \mathrm{pt}$ & Preemergence & $\begin{array}{l}\text { Can provide suppression of seedling sorghum- } \\
\text { almum. Does not control regrowth of underground } \\
\text { runners. Apply prior to weed emergence after } \\
\text { planting or after harvest of stubble cane. }\end{array}$ \\
\hline $\begin{array}{l}\text { Pendimethalin } \\
+ \\
\text { Metribuzin }\end{array}$ & $\begin{array}{l}\text { Prowl } \mathrm{H}_{2} \mathrm{O} \\
+ \\
\text { Metribuzin }\end{array}$ & $\begin{array}{l}11 / 3-22 / 3 \mathrm{lb} \\
+4.2-8.4 \mathrm{pt}\end{array}$ & Preemergence & $\begin{array}{l}\text { Can provide suppression of seedling sorghum- } \\
\text { almum. Does not control regrowth of underground } \\
\text { runners. Apply prior to weed emergence after } \\
\text { planting or after harvest of stubble cane. }\end{array}$ \\
\hline Asulam & $\begin{array}{l}\text { Asulox } \\
\text { Asulam } \\
\text { (several) }\end{array}$ & $6-8 \mathrm{pt}$ & Postemergence & $\begin{array}{l}\text { Apply to plant or stubble cane for suppression of } \\
\text { seedling and rhizome sorghum-almum less than } 18 \\
\text { inches tall. Use either a non-ionic surfactant at } 1-2 \\
\text { quarts per } 100 \text { gallons }(0.25-0.50 \% \mathrm{v} / \mathrm{v}) \text { or crop oil } \\
\text { concentrate at } 4 \text { quarts per } 100 \text { gallons ( } 1 \% \mathrm{v} / \mathrm{v}) \text {. }\end{array}$ \\
\hline $\begin{array}{l}\text { Asulam } \\
+ \\
\text { Trifloxysulfuron }\end{array}$ & $\begin{array}{l}\text { Asulox } \\
\text { Asulam } \\
\text { (several) } \\
+ \\
\text { Envoke }\end{array}$ & $\begin{array}{l}6-8 \mathrm{pt} \\
+0.3 \mathrm{oz}\end{array}$ & Postemergence & $\begin{array}{l}\text { Apply to plant or stubble cane for suppression of } \\
\text { seedling and rhizome sorghum-almum less than } 18 \\
\text { inches tall. Use a non-ionic surfactant at } 1-2 \text { quarts } \\
\text { per } 100 \text { gallons }(0.25-0.50 \% \mathrm{v} / \mathrm{v}) \text {. }\end{array}$ \\
\hline
\end{tabular}

